\title{
FV-1 Restriction of Age-Dependent Paralytic Lactic Dehydrogenase Virus Infection
}

\author{
LARRY R. PEASE, ${ }^{1}$ GERALD D. ABRAMS, AND WILLIAM H. MURPHY²
}

The Department of Microbiology and Immunology, and the Department of Pathology (GDA), The University of Michigan Medical School, Ann Arbor, Michigan 48109

Received June 29, 1981; accepted October 22, 1981

\begin{abstract}
A genetic analysis was made of the susceptibility of inbred mice to a paralytic disease elicited by the ip injection of a neuroparalytic strain of lactic dehydrogenase virus. The frequency of disease in susceptible inbred mice was X-ray dose and age dependent. Analysis of the susceptibility of appropriate $F_{1}$ hybrids and their hackcross progeny showed that susceptibility was not linked to the major histocompatibility complex but segregated with the Fv-1 linkage group. Linkage group analysis showed that resistance to paralytic infection was linked to a single gene outside the major histocompatibility complex. By determining the segregation of $G p d-1$ isozyme variants among backeross progeny it was shown that inheritance of the $F v-1^{b}$ allele resulted in virtually absolute restriction of susceptibility. Genetic evidence was obtained indicating that mice that had multiple copies of $\mathrm{N}$-tropic $\mathrm{C}$-type retroviruses in their genomes, and that were permissive for retrovirus expression $\left(F v-I^{n / n}\right)$, were susceptible to paralytic LDV infection. Strains that carried few copies of $\mathrm{N}$-tropic $\mathrm{C}$-type retroviruses in their genomes, or that inherited the $F v-1^{b}$ allele, were resistant. A significant maternal resistance effect was demonstrable in some backcross generations that appeared to be mediated by $H-2^{b}$ in the major histocompatibility complex.
\end{abstract}

\section{INTRODUCTION}

When C58 mice 9 or more months of age are infected with paralytic strains of lactic dehydrogenase virus $(\mathrm{LDV})^{3}$ they develop a fatal paralytic disease characterized by an inflammatory destruction of motor neurons in the brain stem and cord (Murphy et al., 1980; Nawrocki et al., 1980; Martinez et al., 1980). Demyelination is minimal or absent and the white matter and peripheral nerves are essentially free of lesions (Lawton and Murphy, 1973). Pa-

\footnotetext{
${ }^{1}$ Present address: Department of Microbiology and Immunology, Albert Einstein College of Medicine, 1300 Morris Park Avenue, Bronx, N. Y. 10461.

${ }^{2}$ To whom reprint requests should be addressed.

${ }^{3}$ Abbreviations used: Ib cells, line Ib malignant lymphoid cells; LDV, lactic dehydrogenase virus; $\mathrm{ID}_{50}$, highest dilution of $\mathrm{LDV}$ that infects $50 \%$ of mice; B10, C57BL/10Sn strain; B10.BR, B10.BR/SgSn strain; $\mathrm{C} 58 / \mathrm{Wm}$ mice, $\mathrm{C} 58$ mice; $\mathrm{BALB} / \mathrm{cWm}$ mice, BALB mice; MSSH, modified Hanks' balanced salt solution; MHC, major histocompatibility complex.
}

ralysis is not accompanied by ataxia, tremors, or seizures but parallels motor neuron destruction. Paralysis begins about 9 days after LDV infection, reaches a peak at 13 to 17 days and usually does not develop after 30 days. Only old C58 mice are naturally susceptible. In the C58 strain susceptibility correlates with an age-dependent loss of a T-cell subset required for resistance (Murphy et al., 1980). Of the common inbred mouse strains only AKR, $\mathrm{C} 3 \mathrm{H} / \mathrm{Fg}$, and $\mathrm{PL} / \mathrm{J}$ mice are susceptible provided that they are immunosuppressed by $\mathrm{X}$ irradiation or drugs $24 \mathrm{hr}$ before LDV infection (Pease and Murphy, 1980; Duffey et al., 1976). The resistance of most common inbred strains of mice to the disease indicated that resistance was under strong genetic regulation. The association between the high susceptibility of $\mathrm{C} 58$ and AKR mice to spontaneous leukemia and to the disease, coupled with the extraordinary resistance of nonleukemic strains, suggested that the genes of the major his- 
tocompatibility complex that influence the susceptibility of mice to viral-induced lymphocytic leukemia (Steeves and Lilly, 1977) might also regulate their susceptibility to paralytic LDV infection. Preliminary studies (Duffy et al., 1976) indicated that susceptibility was $H-\mathscr{Q}^{k}$ associated. However, a detailed genetic analysis of susceptibility had to take into account the major variables (Murphy et al., 1980; Nawrocki et al., 1980) known to determine the occurrence of the disease: infection by neurovirulent strains of LDV; the genetic constitution of mice; their age; and $\mathrm{X}$-ray dose effects on susceptibility. In the current study indicator mice were infected with a standard dose of a neurovirulent strain of LDV (Ib-LDV) containing approximately $10^{8} \mathrm{ID}_{50}$. A genetic strategy of analysis was employed so that the effects of genes linked to or outside of the MHC could be evaluated. We report here genetic evidence that the susceptibility of C58 mice to paralytic LDV infection was essentially independent of the major histocompatibility complex. Linkage group analysis in selected test crosses documented that resistance in $\mathrm{F}_{1}$ hybrids was linked to the Fv-1 locus on chromosome 4.

\section{MATERIALS AND METHODS}

Mice. The origin of our strains of C58 and BALB mice and methods of mouse husbandry were described (Plata and Murphy, 1972). NZB/Bl mice were obtained from Dr. Sara Walker at the University of Michigan. AKR-H-2 $/$ Boy breeding stocks were supplied by Dr. Edward Boyse, Memorial Sloan-Kettering Cancer Center, New York. The remaining inbred mice were purchased from The Jackson Laboratory, Bar Harbor, Maine. Hybrid and backcross mice were generated by breeding mice that were between 2 and 5 months of age.

Ib cells. Ib cells originally were derived from the spleen of a C58 mouse with spontaneous leukemia (Richter and MacDowell, 1930). The spleens of mice moribund from transplanted leukemia were harvested aseptically and dispersed in bal- anced salt solution (MSSH) as described previously (Nawrocki et al., 1980; Duffey et al., 1976). Cell suspensions were allowed to stand 3 to 5 min to let gross particles settle. The supernatant cells were transferred to a centrifuge tube and sedimented at $250 \mathrm{~g}$ for $10 \mathrm{~min}$. The supernatant fluid was aspirated and the cells washed twice in MSSH. Total and viable cell counts (trypan blue dye exclusion) were done as described previously (Duffey et al., 1976). Viability was $\geq 96 \%$.

$L D V$ stocks. LDV associated with line Ib cells, or LDV stocks prepared in BALB mice (Nawrocki et al., 1980), had the same paralytic effect in indicator mice. In the described experiments mice were infected by the ip injection $(1 \mathrm{ml})$ of $\mathrm{Ib}$ cells $\left(10^{6.5}\right)$ $\mathrm{X}$ irradiated as described below. The infectivity titer of such preparations was approximately $10^{8} \mathrm{ID}_{50}$. Virus titers were determined as described previously (Nawrocki et al., 1980).

$X$ irradiation. Mice received whole body radiation by means of a Westinghouse Coronado X-ray Therapy Machine that delivered $67 \mathrm{R} / \mathrm{min}$ at a target distance of $70 \mathrm{~cm}$ when operated at $250 \mathrm{kv}$ and $15 \mathrm{~mA}$, using $0.5-\mathrm{mm} \mathrm{Cu}$ and $1.0-\mathrm{mm} \mathrm{Al}$ filters. Viable Ib cells were $X$ irradiated in a 60 $\times 15-\mathrm{mm}$ plastic dish containing 5 to $10 \mathrm{ml}$ of cell suspension $\left(10^{8}\right.$ cells $\left./ \mathrm{ml}\right)$. The machine was operated at $200 \mathrm{kv}$ at $15 \mathrm{~mA}$ through $1-\mathrm{mm} \mathrm{Al} \mathrm{filter} \mathrm{to} \mathrm{produce} \mathrm{a} \mathrm{rate}$ of $537 \mathrm{R} / \mathrm{min}$ at a target distance of $24 \mathrm{~cm}$. A dose of $10,000 \mathrm{R}$ was used.

Induction of disease. Virus preparations (Ib-LDV) were injected ip (1 ml) into mice that had been $\mathrm{X}$ irradiated $24 \mathrm{hr}$ previously. Mice were scored for paralysis over a 30-day period; only unequivocal signs of paralysis were scored positive. The incidence of paralysis was the same in male or female animals regardless of age (Duffey et al., 1976). To assure the accuracy of diagnosis three to six mice in each test group, whether they had overt signs of disease or not, were examined histologically. In the groups of mice in which the incidence of paralysis was low the diagnosis was confirmed histologically.

Histopathology. Paralyzed and disease- 
free mice (three to six per group) were killed, the vertebral columns were removed and fixed in $10 \%(\mathrm{v} / \mathrm{v})$ formalinphosphate-buffered ( $\mathrm{pH} 7.2$ ) $0.85 \% \mathrm{NaCl}$ solution. Each entire column was decalcified and transverse slices of the spinal cord and vertebrae were taken at five levels as described previously (Lawton and Murphy, 1973). Sections were embedded in paraffin, sectioned, and stained with hematoxylin and eosin.

Typing of $H$ - 2 antigens. A two-step complement-dependent cytotoxicity test was used to determine the $H-2$ haplotype of backcross mice. Spleen cell suspensions prepared from mice as described above were enriched for lymphocytes by centrifugation $(400 \mathrm{~g})$ of $5 \times 10^{7}$ cells on a FicollPaque gradient (Pharmacia Fine Chemicals, Piscataway, N. J.); $95 \%$ of the cells collected at the interface were viable (trypan blue dye exclusion). Since backcross mice could have been $H-2^{k / k}$ or $H-2^{k} / H$ $2^{b}$, cell suspensions from animals in each group were tested individually. Antisera to $\mathrm{H}-2.33, \mathrm{H}-2.35, \mathrm{H}-2.36$, and $\mathrm{H}-2.39$ were prepared by immunizing B10.D2 $\times \mathrm{A} \mathrm{F}_{1}$ hybrids with spleen cells from B10.A(5R) donors as described by David et al. (1973). Guinea pig serum (Grand Island Biological Co., Grand Island, N. Y.) was used as the source of complement. Test splenic lymphocytes $\left(10^{6} / \mathrm{ml}\right)$ were incubated with the appropriate dilution of alloantiserum for 30 min at $4^{\circ}$. The cells then were washed with MSSH, resuspended in guinea pig serum (diluted 1:5 in MSSH), and incubated for an additional $30 \mathrm{~min}$ at $37^{\circ}$. Viability was determined by trypan blue dye exclusion.

Gdp-1 typing of backcross mice. The Gpd1 genotypes of backcross mice were determined by starch gel electrophoresis of kidney extracts. The method described by Ruddle et al. (1968) was used except that gels were stained at $60^{\circ}$ for $5 \mathrm{hr}$. Gels prepared from kidney extracts of individual testcross mice were compared with $\mathrm{C58}$ $\left(G p d-1^{\alpha / a}\right)$ and C58 $\times$ BALB $F_{1}$ extracts $\left(G d p-1^{a / b}\right)$ employed as standards.

Statistical methods. $\chi^{2}$ tests and 95\% confidence intervals were calculated as described by Remington and Schork (1970).

\section{RESULTS}

\section{Effects of X-Ray Dose on Susceptibility}

We reported (Duffey et al., 1976; Pease and Murphy, 1980) that age has a significant effect on the phenotypic expression of susceptibility in mouse strains that are genetically susceptible to infection by paralytic strains of LDV. The experiments summarized here were done to define how the dose of whole body $\mathrm{X}$ irradiation affected susceptibility since both X-ray dose and age effects had to be carefully controlled in the genetic analysis of susceptibility. Table 1 shows that 6-month-old C58 mice were fully susceptible to disease after 450,550 , or $600 \mathrm{R}$ of whole body $\mathrm{X}$ irradiation. In the $A K R / J$ strain the incidence of disease in the $450-$ and $550-\mathrm{R}$ groups was 50 and $73 \%$, respectively. In the B10.BR/SgSn strain $11 / 16$ mice in the 600-R group died before paralysis could occur; $3 / 4$ of the surviving mice developed histologically confirmed disease. Since the response of mice moribund from $600 \mathrm{R}$ did not constitute a meaningful test, the 550$\mathrm{R}$ dose of whole body $\mathrm{X}$ irradiation was used to define susceptibility. Since none of the B10.BR mice in the 550-R group developed disease this strain was scored resistant. No histologic evidence of disease was found in these lest animals. None of the remaining strains developed clinical or histologic evidence of disease. The effects of age on susceptibility is defined in Tables 2 and 3 . These tables also list the $H$-2 haplotypes and $F v-1$ genotypes of the test mice to record where parallelisms occurred between susceptibility to paralysis and the mouse genotypes.

\section{Susceptibility of $F_{1}$ Hybrids}

Table 2 compares the susceptibility of $F_{1}$ hybrids obtained when female C58 mice were crossed with male mice of resistant or susceptible strains. The results show that C58 $\times$ AKR hybrids were as susceptible to disease at 6 months of age as at 12. No gene complementation occurred between the two strains to result in resistant progeny. The C58 $\times$ AKR-H- $2^{\text {b }} /$ Boy hybrids were susceptible to disease at both 
TABLE 1

EFFECT OF WHOLE BODY X IRRADIATION ON THE SUSCEPTIBILITY OF INBRED MiCE TO PARALYTIC LDV INFECTION

\begin{tabular}{|c|c|c|c|c|c|c|}
\hline \multirow[b]{2}{*}{ Mouse strain } & \multirow{2}{*}{$\begin{array}{l}H-2 \\
\text { type }\end{array}$} & \multirow{2}{*}{$\begin{array}{l}F v-1 \\
\text { type }\end{array}$} & \multicolumn{4}{|c|}{ Incidence of paralysis when mice received ${ }^{a}$} \\
\hline & & & No X ray & $450 \mathrm{R}$ & $550 \mathrm{R}$ & $600 \mathrm{R}$ \\
\hline $\mathrm{C} 58 / \mathrm{Wm}$ & $\mathbf{k}$ & $\mathbf{n}$ & $0 / 40^{b}$ & $32 / 35$ & $38 / 39$ & $44 / 45$ \\
\hline AKR/J & $\mathbf{k}$ & $\mathbf{n}$ & $0 / 10$ & $16 / 32$ & $11 / 15$ & $17 / 17$ \\
\hline B10.BR/SgSn & $\mathbf{k}$ & b & & & $0 / 18$ & $3 / 4^{c}$ \\
\hline $\mathrm{C} 3 \mathrm{H} / \mathrm{HeJ}$ & $\mathrm{k}$ & $\mathbf{n}$ & $0 / 10$ & $0 / 15$ & & $0 / 15$ \\
\hline $\mathrm{CBA} / \mathrm{J}$ & $\mathbf{k}$ & $\mathbf{n}$ & $0 / 10$ & $0 / 15$ & & $0 / 14$ \\
\hline $\mathrm{BALB} / \mathrm{cWm}$ & $\mathrm{d}$ & $\mathbf{b}$ & $0 / 10$ & $0 / 15$ & & $0 / 15$ \\
\hline $\mathrm{NZB} / \mathrm{Bl}^{d}$ & $\mathrm{~d}$ & & $0 / 9$ & $0 / 19$ & & $0 / 32$ \\
\hline C57BL/6J & b & b & $0 / 10$ & $0 / 15$ & & $0 / 15$ \\
\hline C57BL/10Sn & $\mathbf{b}$ & $\mathbf{b}$ & & $0 / 23$ & $0 / 12$ & $1 / 10$ \\
\hline
\end{tabular}

${ }^{a}$ Six-month-old mice were $\mathrm{X}$ irradiated $24 \mathrm{hr}$ before infection with $10^{8} \mathrm{ID}_{50}$ of LDV. Paralysis was scored over a 30-day period and the diagnosis confirmed histologically in representative animals in each positive group.

${ }^{b}$ Data were compiled from two to four replicate experiments for susceptible strains and from one to three replicate experiments for resistant strains.

${ }^{c}$ Eleven mice in this group of 16 animals were excluded from the experiment because they died from $X$ irradiation before paralysis could occur. In the three positive animals the disease was confirmed histologically.

${ }^{d} \mathrm{NZB} / \mathrm{Bl}$ mice are resistant to infection by both $\mathrm{N}$-tropic and $\mathrm{B}$-tropic mouse leukemia viruses.

6 and 12 months of age. The $\mathrm{C} 58 \times \mathrm{DBA} /$ $2 \mathrm{~J}$ and $\mathrm{C} 58 \times \mathrm{C} 3 \mathrm{H} / \mathrm{HeJ} \mathrm{F}_{1}$ hybrids were susceptible to disease at both 6 and 9 months of age with a tendency toward a higher incidence in the 9-month-old group. C58 females crossed to resistant NZB/Bl,

TABLE 2

SUSCEPTibIlity OF $F_{1}$ HYbrid Mice to Paral ytic LDV INFECTION

\begin{tabular}{|c|c|c|c|c|c|}
\hline \multirow[b]{2}{*}{$F_{1}$ hybrids } & \multirow{2}{*}{$\begin{array}{l}H-2 \\
\text { type }\end{array}$} & \multirow{2}{*}{$\begin{array}{l}F v-1 \\
\text { type }\end{array}$} & \multicolumn{3}{|c|}{ Incidence of paralysis in mice ${ }^{a}$} \\
\hline & & & 6 months & 9 months & 12 months \\
\hline C58 $\times$ AKR & $\mathrm{k} / \mathrm{k}$ & $\mathrm{n} / \mathrm{n}$ & $24 / 29$ & & $13 / 15$ \\
\hline C58 $\times$ AKR-H-2 $/$ Boy & $\mathrm{k} / \mathrm{b}$ & $\mathrm{n} / \mathrm{n}$ & $14 / 34$ & & $12 / 14$ \\
\hline $\mathrm{C} 58 \times \mathrm{DBA} / 2 \mathrm{~J}$ & $\mathrm{k} / \mathrm{d}$ & $n / n$ & $2 / 8^{b}$ & $5 / 8$ & \\
\hline $\mathrm{C} 58 \times \mathrm{C} 3 \mathrm{H} / \mathrm{HeJ}$ & $\mathrm{k} / \mathrm{k}$ & $\mathrm{n} / \mathrm{n}$ & $2 / 8$ & $7 / 12$ & \\
\hline $\mathrm{C} 58 \times \mathrm{NZB} / \mathrm{Bl}$ & $\mathrm{k} / \mathrm{d}$ & & $0 / 20$ & $0 / 7$ & \\
\hline $\mathrm{C} 58 \times \mathrm{B}^{\circ} 0^{\mathrm{c}}$ & $\mathrm{k} / \mathrm{b}$ & $\mathrm{n} / \mathrm{b}$ & $0 / 26$ & & $0 / 10$ \\
\hline C58 $\times$ B10.BR & $\mathrm{k} / \mathrm{k}$ & $\mathrm{n} / \mathrm{b}$ & $0 / 20$ & & $0 / 14$ \\
\hline $\mathrm{C} 58 \times \mathrm{BALB}$ & $\mathrm{k} / \mathrm{d}$ & $\mathrm{n} / \mathrm{b}$ & $0 / 11$ & & $0 / 19$ \\
\hline
\end{tabular}

${ }^{a}$ All mice received $550 \mathrm{R}$ of $\mathrm{X}$ irradiation $24 \mathrm{hr}$ before infection with $\mathrm{LDV}$ and were scored for paralysis as described in Table 1. Data were compiled from two to six replicate experiments. The female is listed first in each cross.

${ }^{b}$ Differences in the incidence of disease in the 6- and 9-month-old C58 $\times \mathrm{DBA} / 2 \mathrm{~J}$ and $\mathrm{C} 58 \times \mathrm{C} 3 \mathrm{H} / \mathrm{HeJ}$ mice were not statistically significant.

${ }^{c}$ C57BL/10Sn and B10.BR/SgSn are designated B10 and B10.BR, respectively. 
B10, B10.BR, and BALB mice yielded resistant progeny. Susceptibility was confined to the $\mathrm{F}_{1}$ hybrids that were $F v-I^{n / n}$.

\section{Susceptibility of Backcross Progeny}

Two sets of mice (Table 3) were employed to assess the susceptibility of backcross progeny. In groups 1 through 3 resistant $F_{1}$ females were crossed with resistant males. In groups 4 through 9 reciprocal crosses were made between susceptible C58 mice (male or female) and resistant $F_{1}$ hybrids (male or female). Table 3 shows that all of the progeny of the resistant backcrosses (groups 1 through 3) were resistant, i.e., no gene combinations or sex-linked events occurred to make the progeny susceptible. When group 4 was compared with group 5 a much lower incidence of disease was observed in the progeny that nursed on the resistant C58 $\times$ B10 mothers (group 5). An analogous result is seen when groups 6 and 7 are compared. Since the frequency of disease in mice is not influenced by sex (Duffey et al., 1976), the effects seen in groups 5 and 7 represent a non-Mendelian resistance cffect mediated by the $\mathrm{C} 58 \times \mathrm{B} 10$ mothers in group 5 and the C58 $\times$ BALB mothers in group 7 . When identical experiments were done using congenic
B10.BR mice in place of B10 (compare groups 4 and 5 with 8 and 9) no maternal resistance effect was found. Since B10.BR mice are $H-2^{k}$ and B10 mice are $H-2^{b}$ the results suggest that the $H-Q^{b}$ haplotype had a significant effect on maternal resistance in the $(\mathrm{C} 58 \times \mathrm{B} 10) \times \mathrm{C} 58$ backcross. The data for the testcross progeny in groups 4 and 9 also show that susceptibility was age dependent. In these groups Mendelian theory predicts that $50 \%$ of the testcross progeny would be $F v-1^{n / n}$. In mice old enough to be fully susceptible the incidence of disease was $50 \%$.

\section{Haplotypes of Backcross Mice and Suscep- tibility to Disease}

The effects of the MHC on the susceptibility to viral infection are known to be complex (see review, Amos, 1980). Therefore direct tests were done to determine whether the MHC affected susceptibility in a representative group of testcross mice (group 3, Table 3). Spleen cells obtained from testcross mice either with or without disease were typed for the appropriate $H$ 2 antigens as described under Materials and Methods. If one assumes that $H-2$ is without effect on susceptibility the ratio of $H-2^{k} / H-2^{b}$ heterozygotes to $H-2^{k} / H-2^{k}$ homozygotes should approximate 1:1

TABLE 3

Susceptibility of BackCross Progeny to Paralytic LDV INFECtion

\begin{tabular}{|c|c|c|c|c|c|c|c|}
\hline \multirow[b]{2}{*}{ Group } & \multirow[b]{2}{*}{ Backcross progeny } & \multirow{2}{*}{$\begin{array}{l}\text { Phenotype } \\
\text { of parents }\end{array}$} & \multirow[b]{2}{*}{$H-2$ type } & \multirow[b]{2}{*}{$F v \cdot 1^{a}$ type } & \multicolumn{3}{|c|}{ Incidence of paralysis in mice $a t^{b}$} \\
\hline & & & & & 6 months & 9 months & 12 months \\
\hline 1 & $(\mathrm{C} 58 \times \mathrm{B} 10) \times \mathrm{B} 10$ & $\mathbf{R} \times \mathbf{R}^{\mathbf{e}}$ & $k / b$ or $b / b$ & $n / b$ or $b / b$ & $0 / 43$ & & \\
\hline 2 & $(\mathrm{C} 58 \times \mathrm{B} 10) \times \mathrm{B} 10 . \mathrm{BR}$ & $\mathrm{R} \times \mathrm{R}$ & $k / k$ or $k / b$ & $b / b$ or $n / b$ & $0 / 34$ & & \\
\hline 3 & $(\mathrm{C} 58 \times \mathrm{B} 10 . \mathrm{BR}) \times \mathrm{B} 10 . \mathrm{BR}$ & $\mathrm{R} \times \mathrm{R}$ & $\mathbf{k} / \mathbf{k}$ & $b / b$ or $n / b$ & $0 / 38$ & & \\
\hline 4 & $\mathrm{C} 58 \times(\mathrm{C} 58 \times \mathrm{B} 10)$ & $\mathbf{S} \times \mathbf{R}$ & $\mathrm{k} / \mathrm{k}$ or $\mathrm{k} / \mathrm{b}$ & $n / n$ or $n / b$ & $18 / 53$ & & $6 / 12$ \\
\hline 5 & $(\mathrm{C} 58 \times \mathrm{B} 10) \times \mathrm{C} 58$ & $\mathbf{R} \times \mathbf{S}$ & $\mathrm{k} / \mathrm{k}$ or $\mathrm{k} / \mathrm{b}$ & $\mathrm{n} / \mathrm{n}$ or $\mathrm{n} / \mathrm{b}$ & $1 / 93^{d}$ & & $1 / 20$ \\
\hline 6 & $\mathrm{C} 58 \times(\mathrm{C} 58 \times \mathrm{BALB})$ & $\mathbf{S} \times \mathbf{R}$ & $\mathrm{k} / \mathrm{k}$ or $\mathrm{k} / \mathrm{d}$ & $n / n$ or $n / b$ & & $13 / 32^{d}$ & \\
\hline 7 & $(\mathrm{C} 58 \times \mathrm{BALB}) \times \mathrm{C} 58$ & $\mathrm{R} \times \mathrm{S}$ & $\mathrm{k} / \mathrm{k}$ or $\mathrm{k} / \mathrm{d}$ & $\mathrm{n} / \mathrm{n}$ or $\mathrm{n} / \mathrm{b}$ & & $0 / 15$ & \\
\hline 8 & $\mathrm{C} 58 \times(\mathrm{C} 58 \times \mathrm{B} 10 . \mathrm{BR})$ & $\mathbf{S} \times \mathbf{R}$ & $\mathrm{k} / \mathrm{k}$ & $n / n$ or $n / b$ & $20 / 46$ & & $7 / 15$ \\
\hline 9 & $(\mathrm{C} 58 \times \mathrm{B} 10 . \mathrm{BR}) \times \mathrm{C} 58$ & $\mathbf{R} \times \mathbf{S}$ & $\mathrm{k} / \mathrm{k}$ & $n / n$ or $n / b$ & $28 / 77$ & & $8 / 16$ \\
\hline
\end{tabular}

a See Table 1 for the $F v-1$ type of the parental strains.

'Experiments were carried out as described in Table 2. In each testcross the females are listed first. Data were compiled from three to six replicate experiments.

c R, Resistant; S, susceptible.

${ }^{d}$ The positive mice in these testcrosses had histologically confirmed disease; those free of disease had no histologic evidence for disease. 
among the resistant and susceptible progeny. The results showed that of 26 resistant mice 11 were $H-2^{k} / H-2^{b}$ while 15 were $H-\mathscr{2}^{k} / H-2^{k}$. In the susceptible group there were $6 / 12$ heterozygotes and $6 / 12$ homozygotes. This distribution approximates the result expected if $H-2$ were without effect on susceptibility or resistance. However, it does not mean (Steeves and Lilly, 1977; Amos, 1980) that the MHC will not have an effect in all testcrosses.

\section{Linkage Groups Conferring Resistance in B10 and B10.BR Backcrosses}

Since no $H-2$ or maternal effects were seen in the testcross progeny in groups 4 , 8 , and 9 in Table 3 , the incidence of disease in mice of these backcrosses was used to estimate the number of non- $H-2$ linkage groups that regulated resistance in $\mathrm{C} 58$ $\times \mathrm{B} 10$ and $\mathrm{C} 58 \times \mathrm{B} 10 . \mathrm{BR} \mathrm{F}_{1}$ hybrids listed in Table 2. By assuming that each relevant linkage group conferred complete resistance, the ratio of resistant to susceptible progeny in the appropriate testcrosses could be predicted from the equation 1-(1/ $2)^{n} /(1 / 2)^{n}$, where $n$ is the number of resistance-conferring linkage groups. For 6month-old mice the pooled data (Table 4) gave a value of 1.42 linkage groups, a result reflecting the incomplete susceptibility of 6-month-old indicator animals. In the fully susceptible 12-month-old mice the incidence of susceptibility was cssentially $50 \%$ in all test groups thus providing evidence that resistance to disease was linked to one gene outside the major histocompatibility complex.

\section{Gpd-1 Genotypes of Susceptible and Resis- tant Mice}

Except for the maternal resistance effects described above, the data in Tables 1 through 3 , and those reported previously (Pease and Murphy, 1980), have shown that susceptibility to paralytc LDV infection was largely independent of the MHC and appeared to be primarily regulated by a single gene at the $F v-1$ locus on chromosome 4. Since the alleles for glucose-6dehydrogenase $(G d p-1)$ isoezymes $a$ and $b$ are tightly linked to $F v$ - 1 (Rowe and Sato, 1973), they served as reliable markers to test directly whether disease susceptible or resistant backcross mice were of the $F v-1$ genotypes predicted on the basis of Mendelian inheritance. Thus, C58 $\times($ C58 $\times$ BALB) testcross progeny that were tested for their susceptibility to paralytic infection (group 6, Table 3) were typed individually for the inheritance of $G p d-1^{a}$ (C58 mice are homozygous for the $a$ allele) or $G p d-1^{b}$ alleles (BALB mice are homozygous for the $b$ allele). Kidney extracts from a total of 18 mice were typed for the $G p d-I^{a}$ and $G p d-1^{b}$ isoenzymes as described under Materials and Methods. The results showed that $12 / 13$ susceptible testcross mice were homozygous for the C58 derived $G p d-1^{a}\left(F v-1^{n}\right)$ allele. All five resistant mice were $G p d^{a / b}\left(F v-1^{n / b}\right)$. However, one $G p d^{a / b}\left(F v-1^{n / b}\right)$ heterozygous mouse was susceptible thus suggesting that either a rare recombinational event occurred between the $F v-1$ and $G p d-1$ genes, or that $F v-1^{b}$ restriction is not absolute in this experimental model.

\section{DISCUSSION}

Because the susceptibility of C58 mice to paralytic LDV infection has a multifactorial basis (Murphy et al., 1980; Nawrocki et al., 1980; Duffey et al., 1976) a genetic analysis of susceptibility required that each of the variables that regulated disease expression be defined accurately. By holding the infecting dose of LDV constant in all experiments it was possible to evaluate the effects of $x$-ray dose and age on susceptibility. As shown in Tables 1-3 $\mathrm{X}$-ray dose and age had a significant effect on the susceptibility of the various inbred strains, their $F_{1}$ hybrids, and backcross progeny. Once these effects were characterized it was possible to evaluate whether the genes of the major histocompatibility complex regulated susceptibility. In the current study "susceptible" was defined to mean the occurrence of clinical and histopathologically confirmed disease in mice of a genetically uniform group under appropriately defined test conditions.

Several lines of evidence supported the 
TABLE 4

LiNKage Groups CoNFERRING RESISTANCE IN B10 AND B10.BR BACKCROSSES

\begin{tabular}{lcccc}
\hline \multicolumn{1}{c}{ Backcross } & $\begin{array}{c}\text { Age of mice } \\
(\text { months })\end{array}$ & $\begin{array}{c}\text { Incidence of } \\
\text { susceptible } \\
\text { mice }^{n}\end{array}$ & $\begin{array}{c}\text { Frequency } \\
(f)\end{array}$ & $\begin{array}{c}\text { Estimated number of } \\
\text { linkage groups }(n)^{b}\end{array}$ \\
\hline $\mathrm{C} 58 \times(\mathrm{C} 58 \times \mathrm{B} 10)$ & 6 & $18 / 53$ & $0.34( \pm 0.13)^{c}$ & $1.56(1.10-2.24)$ \\
$\mathrm{C} 58 \times(\mathrm{C} 58 \times \mathrm{B} 10 . \mathrm{BR})$ & 12 & $6 / 12$ & $0.50( \pm 0.28)$ & $1.00(0.35-2.18)$ \\
& 6 & $20 / 46$ & $0.46( \pm 0.14)$ & $1.20(0.79-1.78)$ \\
$(\mathrm{C} 58 \times \mathrm{B} 10 . \mathrm{BR}) \times \mathrm{C} 58$ & 12 & $7 / 15$ & $0.47( \pm 0.25)$ & $1.08(0.48-2.18)$ \\
& 6 & $28 / 77$ & $0.36( \pm 0.11)$ & $1.46(1.17-1.96)$ \\
Pooled data & 12 & $8 / 16$ & $0.50( \pm 0.24)$ & $1.00(0.44-1.71)$ \\
& 6 & $66 / 176$ & $0.37( \pm 0.07)$ & $1.42(1.17-1.72)$ \\
& 12 & $21 / 43$ & $0.49( \pm 0.15)$ & $1.03(0.64-1.56)$ \\
\hline
\end{tabular}

\footnotetext{
${ }^{a}$ Data from groups 4, 8, and 9, Table 3.

${ }^{b}$ Calculated from the equation $f=(1 / 2)^{n}$ where $(f)$ is the incidence (frequency) of susceptible mice in each testeross and $(n)$ is the number of linkage groups conferring resistance.

c $95 \%$ confidence intervals around estimated frequency.
}

conclusion that resistance or susceptibility to the described disease was not linked to the major histocompatibility complex. Table 2 shows that the susceptibility of $F_{1}$ hybrids depended on the crosses made, was independent of the MHC, and could be either dominant or recessive. Thus, when resistant $\mathrm{B} 10\left(H-\mathcal{Q}^{b}\right)$ or $\mathrm{B} 10 . \mathrm{BR}\left(H-2^{k}\right)$ male mice were mated with $\mathrm{C} 58$ females $\left(H-2^{k}\right)$ resistance was dominant in the $\mathrm{F}_{1}$ hybrids. However, when resistant DBA/ $2 \mathrm{~J}\left(H-2^{d}\right)$ or $\mathrm{C} 3 \mathrm{H} / \mathrm{HeJ}\left(H-\mathscr{2}^{k}\right)$ male mice were similarly bred to $\mathrm{C} 58$ females the hybrids were susceptible. The AKR-H-2 Boy strain $\left(H-2^{b}\right)$ that is congenic to AKR/ $\mathrm{J}\left(H-2^{k}\right)$ was susceptible to the disease thus indicating that resistance was not determined by the $H-2^{b}$ haplotype. The backcross studies involving crosses of resistant $\mathrm{F}_{1}$ hybrids to resistant parents failed to generate (Table 3, groups 1-3) susceptible recombinants. In breeding groups 4,8 , and 9 in Table 3 , where resistant $F_{1}$ hybrids were backcrossed reciprocally to susceptible parents, $50 \%$ of the testcross progeny were susceptible to paralytic infection provided that they were aged sufficiently to permit full expression of susceptibility. The frequence of susceptibility was independent of the MHC genotype of the parents. The data in Table 4 document that resistance was linked to a single gene outside of the MHC. A backcross analysis of the regulatory effect of the $F v-1$ locus on susceptibility (Table 3), combined with the typing of resistant and susceptible testcross mice for the $F v$-1-linked $G p d-1$ locus, provided reasonable evidence that susceptibility to paralytic LDV infection was regulated primarily by the $F v-1$ locus.

The regulatory effect of the $F v-1$ locus on susceptibility was puzzling since $F v-1$ alleles are not known to restrict LDV replication in mice, various mouse strains do not appear to differ in susceptibility to infection, and maternal resistance effects in LDV infections have not been reported (reviewed in Rowson and Mahy, 1975). The possibility that C-type or B-type retrovirus infection was required to elicit disease in LDV-infected mice, was supported by several lines of evidence. The backcross data in Table 3 serve as an example. The $(\mathrm{C} 58 \times \mathrm{B} 10) \times \mathrm{C} 58$ testcross progeny in group 5 had a low frequency of disease compared with their reciprocal backcross (group 4). The (C58 $\times$ BALB) $\times$ C58 testcross progeny (group 7) also had a low frequency of disease compared with their reciprocal backcross (group 6). Since susceptibility to paralytic infection is not influenced by sex (Murphy et al., 1980; Duf- 
fey et al.,1976), the classical interpretation of such a result is that resistance was influenced by some non-Mendelian maternal effect in these groups. The described findings suggested that either C- or B-type retrovirus infection was involved in the pathogenesis of the disease, e.g., such viruses (Melief et al., 1975), or antiviral resistance factors (Chen et al, 1980), either were maternally transmitted to their progeny or not. The fact that hybrid parents derived from the B10.BR $H$ - 2 congenic strain did not transmit maternal resistance suggested that genes linked to the major histocompatibility complex may have influenced maternal transmission of the appropriate factors. This association of $H-2$ with maternal inheritance has not been analyzed.

The genetic experiments also provided evidence that the retrovirus(es) presumed to be involved in the pathogenesis of the disease were $\mathrm{N}$-tropic $\mathrm{C}$-type endogenous viruses. The results reported here confirmed our preliminary findings (Pease and Murphy, 1980) that only mouse strains that carried multiple copies of N-tropic Ctype retroviruses in their genomes (Chattopadhyay et al., 1974) and were $F v-I^{n / n}$ were susceptible. Moreover, when mice that were $F v-1^{n / n}$, but carried few copies of $\mathrm{N}$-tropic $\mathrm{C}$-type retroviruses in their genomes, were bred to C58 females and the progeny allowed to nurse on C58 mothers, the offspring were susceptible. Presumably C58 $\mathrm{N}$-tropic C-type retroviruses were transmitted from the C58 mothers to the genetically susceptible but virus-deficient strains thus making them susceptible to paralytic LDV infection. Although the reported data show that the $F v-I^{b}$ allele had virtually an absolute effect on susceptibility, and presumably was restrictive for retrovirus expression, no experiments were done to prove this point. If our hypothesis is correct that endogenous retrovirus infection and expression, combined with coinfection by a virus common to mice was required to elicit paralytic disease, it may provide an additional basis to analyze the pathogenesis of age-dependent neurologic diseases of man of suspected viral etiology.

\section{ACKNOWLEDGMENTS}

Larry R. Pease was a postdoctoral fellow of the Damon Runyon-Walter Winchell Cancer Fund. This work was supported by Grant SO7-RR-05383 from the National Institutes of Health, United States Public Health Service, and the Damon Runyon-Walter Winchell Cancer Fund Grant DRG-190-FT.

We are grateful to Dr. Allen Mayer of the Department of Pathology, New York University School of Medicine, for typing of the Gpd-1 genotypes.

\section{REFERENCES}

Amos, D. B. (1980). Genetic control of natural resistance to viral infections. In "Genetic Control of Natural Resistance to Infection and Malignancy" (E. Skamene, P. A. L. Kongshaun, and M. Landy, eds.), pp. 381-387. Academic Press, New York.

Chattopadhyay, S. K., Lowy, D. R., TeICH, N. M., LEvINE, A. S., and Rowe, W. R. (1974). Qualitative and quantitative studies of AKR-type murine leukemia virus sequences in mouse DNA. Cold Spring Harbor Symp. Quant. Biol. 39, 1085-1101.

Chen, S., Struuck, F. C., Duran-Reynals, M. L., and LILLY, F. (1980). Genetic and non-genetic factors in expression of infectious murine leukemia viruses in mice of the $\mathrm{DBA} / 2 \times \mathrm{RF}$ cross. Cell 21, 849-855.

David, C. S., Shreffler, D. C., and Frelinger, J. A. (1973). New lymphocyte antigen system (Lna) controlled by Ir region of mouse $\mathrm{H}-2$ complex. Proc. Nat. Acad. Sci. USA 70, 2509-2514.

Duffey, P. S., MaRTINez, D., ABRams, G. D., and MurPhy, W. H. (1976). Pathogenic mechanisms in immune polioencephalomyelitis: Induction of disease in immunosuppressed mice. J. Immunol 116, 475-481.

LAWTON, J. W. M., and MuRPHY, W. H. (1973). Histopathology of immune polioencephalomyelitis in C58 mice. Arch. Neurol. 28, 367-370.

Martinez, D., Brinton, M. A., TaChovsky, T. G., and PhelPS, A. H. (1980). Identification of lactate dehydrogenase-elevating virus as the etiologic agent of genetically restricted, age-dependent polioencephlomyelitis of mice. Infect. Immunol 27, 979987.

MELIEF, C. J. M., LoUIE, S., and SwakTZ, R. S. (1975). Ecotropic leukemia viruses in congenic C57BL mice: Natural dissemination by milk borne infection. J. Nat. Cancer Inst. 55, 691-698.

MurPhy, W. H., NaWrockI, J. R., and PEASE, L. R. (1980). Aetiological mechanisms in age dependent murine motor neurone disease. In "Animal Models of Neurological Disease" (F. C. Rose and P. O. Behan, eds.), pp. 123-235. Pitman Med., Tunbridge Wells. 
Nawrocki, J. F., Pease, L. R., and MURPhy, W. H. (1980). Etiologic role of lactic dehydrogenase virus infection in age-dependent neuroparalytic disease in C58 mice. Virology 103, 259-264.

Pease, L. R., and MURPHY, W. H. (1980). Coinfection by lactic dehydrogenase virus and C-type retrovirus elicits neurological disease. Nature (London) 286, 398-400.

Plata, E. J., and MURPHY, W. H. (1972). Growth and hematologic properties of the BALB/Wm strain of inbred mice. Lab. Animal Sci. 22, 712-720.

REMINGTON, R. D., and SCHORK, M. A. (1970). "Statistics with Application to Biological and Health Sciences" Chaps. 7, 10. Prentice-Hall, Engelwood Cliffs, N. J.

Richter, M. N., and MACDowell, E. C. (1930). Stud- ies on leukemia in mice. I. The experimental transmission of leukemia. J. Exp. Med. 51, 659-673.

Rowe, W. P., and SATO, H. (1973). Genetic mapping of the Fv-1 locus of the mouse. Science 180, 640641.

Rowson, K. E. K., and MAHY, B. W. J. (1975). Lactic dehydrogenase virus. In "Virology Monographs" Vol. 13. Springer-Verlag, New York.

RUdDLE, F. H., SHOWS, T. B., and RoDERICK, T. H. (1968). Autosomal control of an electrophoretic variant of glucose-6-phosphage dehydrogenase in the mouse (Mus musculus). Genetics 58, 599-606.

STEEVES, R., and LILLY, F. (1977). Interactions between host and viral genomes in mouse leukemia. Annu. Rev. Genet. 11, 277-296. 